\title{
Effects of Stable Dividend Policy on Market Value of Listed Firms at Nairobi Securities Exchange
}

\begin{abstract}
Justus Maundu Wambua
Laikipia University, Kenya

ABSTRACT

Companies listed at the Nairobi Securities Exchange usually record varied market performance due to decisions they make regarding investments, financing and dividends. Several scholars put across different theories to explain dividend behavior of various markets and firms. Developed markets have been said to pursue dividend policy of stability different from that of developing market firms. This study attempted to investigate the effect of stable dividend policy on market value of listed firms at the Nairobi Securities Exchange. Effect of stable policy was investigated through the use of ANOVA and regression analysis to gain insight into the importance as value enhancing tools. A panel data of firm-year observation from 38 firms purposively selected from the year 2006 to 2015 was investigated and analyzed using descriptive and inferential statistics at the 0.05 level of significance to understand role of dividend policy in a firm's market value. Among the key findings of the study are that dividends paid are related strongly $(\mathrm{r}=0.8)$ to the market price per share. In addition dividend stability is preferred by investors in the market since the value of shares paying stable dividends is 61.65. Recommendation therefore is; listed firms managers should consider paying dividends to shareholders since it is value enhancing. Further dividend payout should not vary widely on a year to year basis since stability is what investors are keen on. This result mean that dividends convey important information about firms financial prospects and future profitability especially when asymmetric information characterize the market. Thus the study contributes to the debate on dividends role in market value addition and shows how financial managers should view payout of dividends in this market.
\end{abstract}

Keywords: Dividend Policy, Kenya, Nairobi Securities Exchange

DOI: $10.7176 / \mathrm{EJBM} / 11-30-11$

Publication date:October $31^{\text {st }} 2019$

\section{INTRODUCTION}

In Kenya, sixty-one companies are listed in the Nairobi Securities Exchange (NSE), which is the only stock exchange firm in the country (Nairobi Securities Exchange, 2015). Listed companies fall into two main segments, that is, the main investment market segment and the alternative investment market segment. The NSE has classified these companies into eleven sectors. These are; Agricultural, Automobiles and Accessories, Banking, Commercial and Services, Construction and Allied, Energy and Petroleum, Insurance, Investment, Investment services, Manufacturing and Allied and Telecommunication and Technology (NSE, 2015).

Dividends are commonly defined as the distribution of earnings (past or present) in real assets among the shareholders of the firm in proportion to their ownership. It is the benefit of shareholders in return for their risk and investment and is determined by different factors in an organization. When the firm constantly pays a fixed amount of dividend and maintains it for all times to come regardless of fluctuations in the level of its earnings, it is called a stable dividend policy. This policy is considered as a desirable policy by the management of companies. Most of the shareholders also prefer stable dividends because all other things remaining same, stable dividends have a positive impact on the market price of the share. By stability, we mean maintaining their positions in relation to a trend live preferably one that is upward sloping.

Several factors contribute to firms' Market value. It differs between small and large firms and may vary from country to country, depending on their economic, geographical and cultural differences. In the study on small business performance, Morrison et al. (2003) noted that human factor was considered the overwhelming force that determines whether a business will prosper or not. There are many different ways to measure value of the firm, but all measures should be taken in aggregation. Line items such as revenue from operations, operating income or cash flow from operations can be used as well as total unit sales.

Dividend policy is therefore, considered to be one of the most important financial decisions that corporate managers encounter (Baker and Powell, 1999). It has potential implications for share prices and hence returns to investors, the financing of internal growth and the equity base through retentions together with its gearing and leverage (Omran \& Pointon, 2004). Frankfurtet \& McGoun (2000) concluded that the dividend puzzle, both as a share value-enhancing feature and as a matter of policy is one of the most challenging topics of modern financial economics. Mizuno (2007) agrees to the fact that a firm ought to pay dividends to shareholders if it cannot identify 
suitable investments which would bring higher returns than those expected by the shareholders. This research therefore tries to establish whether a relationship exists between stable dividend policy and firms market.

\section{Statement of the Problem}

Companies listed at the Nairobi securities exchange usually record different market values because of various decisions made on either investment, financing or dividends. Dividend decisions are known to impact share price positively or negatively depending on investor preference when it comes to dividend policy. Dividend policies have been studied by various scholars with results that are inconclusive in both developed and developing capital markets. Lintner 1956, fama \& Babiak 1968, Brav et al, Aivazian et al. 2003 and Bulla 2017 have studied how dividend policy impacts firm value. Different approaches were used with different variables investigated. Since results have continued to be mixed, this study attempts to contribute to this debate with a different analytical approach. It is designed as a difference test that seeks to examine how stable dividend policy seen to be exhibited by the public firms impact share value of listed firms at the Nairobi Securities Exchange. Dividends policy measured by the current dividends paid per share is the main predictor of market price of the stocks at the exchange. The policy is examined to find out how each contribute to the value of stock from the firm-year observations collected from annual financial reports provided by the stock market. Panel data is investigated using a random effects approach. Size of the firms was also used to determine effect on the relationship between dividend policy and firm value with the hypotheses tested at the $95 \%$ confidence level.

\section{Objective}

The main objective of this study is to investigate the effect of stable dividend policy on market value of listed firms at the Nairobi Securities Exchange in Kenya.

\section{Hypothesis}

There is no statistically significant effect of stable dividends policy on firms' market value.

\section{Significance of the Study}

This study tried to unfold the effect of stable dividend policy on market value of listed firms at the Nairobi Securities Exchange. Given the diversity in corporate objectives and environments, it is conceivable to have divergent dividend policies that are specific to firms, Industries, markets or regions. Through the study, conclusion was reached to suggest how stable dividend policy relates to value creation in the capital market. Further, for the dividend policy makers of listed companies, the study may prove to be useful for re-sketching their dividend policy to enhance share value for investors. Through the study, investors shall have better understanding of dividend payout behavior of firms at NSE and would hence improve their investment decisions based on payout pattern. It may also give insight into what extend is importance it is for the listed firms to adopt stable dividend policy.

\section{Scope}

The study is carried out on 38 firms listed at the Nairobi securities exchange for a period of ten years, from 2006 to 2015 and focused on panel data (firm-year observations) for the period. Stable dividend policy is examined to establish how and to what extend it affects the market value. Firm size was also introduced to see its potential impact on the dividend decisions in the market.

\section{Limitations}

This study was mainly concentrated on the dividend policy decisions and its effects on firm's market value in prospect of Kenya's listed firms at NSE. The data was obtained entirely from the capital market and organized based on the design of study and previous studies to find the answer to the question of how stable dividend policy influences firm value at NSE.

\section{THEORETICAL LITERATURE REVIEW}

Linter (1956) conducted a study, which focused in the behavioral aspect of dividend policy. He investigated dividend pattern of 28 different companies of America and found that, firm generally predetermines the desired payout and tries to achieve it and rarely considers other factors including the firms future performance. Major finding of this study are as follows: First, the firms generally prefer desired proportion of earning to be paid as dividend. Second, investment opportunities and firm's performance are not considered for modifying the pattern of dividend behavior and finally the firm generally have target payout ratios in view while determining change in dividend per share.

Walter (1957) proposed a model for share valuation which supports the view that the dividend policy of the firm has impact on share valuation which in turn may affect the firm's market value. His works shows clearly the importance of the relationship between the firm's internal rate of return on investments (r) and its cost of capital 
(k) in determining the dividend policy that will maximize the wealth of shareholders. In Walter's model the optimum dividend policy depends on the relationship between the firm's internal rate of return on investment (ROI) and its cost of capital (Ke). Thus, in Walter's Model the dividend policy of the firm depends on the availability of investment opportunities and the relationship between the firm's internal rate of return (ROI) and its cost of equity $(\mathrm{Ke})$.

Modigliani and Miller's (1961) model (M-M) avers that dividend policy of the firm is irrelevant. It doesn't affect the wealth of the shareholder. They argue that the value of the firm depends on the firms earning, which result from its investment policy. The literature suggests that dividend payments should have no impact on shareholders' value in the absence of taxes and market imperfections. Hence, companies should invest excess funds in the positive net present value projects instead of paying out them to the shareholders. A firm, which pays dividends, will have to raise funds externally to finance its investment plans.

Gordon (1962) develops own very popular model explicitly relating the market value of the firm to dividend policy. Gordon made a study on the dividend policy and market price of the stock and concluded that the dividend policy of a firm influences the market value of stock. He explained the investor's preferred present dividend rather than future capital gains. He further explained that the dividend policy has direct relation with the value of stock even if the internal rate of return is equal to the required rate of return.

Stephen Ross in 1977 developed information signaling theory. He argued that if stock markets are efficient then the management can use the dividend policy to signal some important information to investors. Therefore, if a company pays high dividends, it shows that the company is profitable and will be able to maintain high dividends in the future. Management may have access to inside information, causing an "information asymmetry" between management and stockholders. Signaling refers to the use of dividends and dividend changes to convey information to investors. Similar to the clientele effect, it is not the absolute but rather the relative level of dividends that is important. Under this argument, management will avoid increasing dividends unless it is highly likely that the higher level of dividends can be maintained.

The clientele effect indicates that investors will tend to hold stocks whose dividend policy fits their needs. That is, investors preferring more certain dividends over uncertain future earnings, or having a preference for current income over capital gains, will tend to hold stocks with relatively high dividend payout, and vice versa (i.e., a stock will have a clientele attracted by its dividend policy). Under these conditions, it is not the dividend policy itself that is relevant, but the stability of the policy. The theory was developed by Richard Petit in 1977.

\section{Empirical Literature Review}

The area of dividend policy has attracted attention of management scholars and economists culminating into theoretical modelling and empirical examination. Thus, dividend policy is one of the most complex aspects in finance. As Black (1976) in his study on dividend wrote, "The harder we look at the dividend picture the more it seems like a puzzle, with pieces that just don't fit together”. Why shareholders like dividends and why they reward managers who pay regular increasing dividends is still unanswered. According to Brealey and Myers (2002) dividend policy has been kept as the top ten puzzles in finance. The most pertinent question to be answered here is that how much cash should firms give back to their shareholders? Should corporations pay their shareholders through dividends or by repurchasing their shares, which is the least costly form of payout from tax perspective? Firms must take these important decisions period after period (some must be repeated and some need to be revaluated each period on regular basis.)

Ndirangu (2014) studied effect of dividend policy on future financial performance of listed firms at NSE. This study adopted a co-relational research design, a sample size was 43, and their annual financial reports for the years 2009-2013. It was established that the current operating accruals, non-current operating accruals and retained cash flows represent significant sources of variation in dividend payments. Kiuru (2014) investigated the relation between dividend payout and performance of listed firms at NSE. The study used audited financial statements to determine the relationship between dividends and performance of firms and revealed exists of a relation between dividends and performance of firms. In addition, the study established a positive relation between net profit after tax and total assets, revenues and dividends but not to what extend.

Njoroge (2001) examined the correlation between dividend framework and firm profitability for listed firms at NSE and found out that there existed a significant and positive relationship between dividend payout and firms earnings. Wairimu (2002) examined the relationship between dividend and investment decisions among the listed firms at NSE Kenya. She inferred that in Kenya, investment decisions are influenced by competitive investment 
choices in light of the fact that the two, investment and dividend decisions consider the assets, accessibility of the assets, cost and obligation of the firm.

Karanja (1987) studied dividend practices of publicly quoted companies in Kenya by collecting data through a questionnaire and obtained information about the kind of dividend policies managers of the quoted companies pursued. He found out three factors to be the most important determinants of dividend policy i.e. cash, liquidity and the amount of earnings. He found that dividend is also influenced by the attitude of the board of directors though he concluded that many companies followed a stable dividend policy. Abdul (1993) conducted a study to identify the parameters, which are important in the determination of dividends by publicly quoted Companies in Kenya and concluded that liquidity is the most important factor in determining dividend policies.

Ikame and Muigai (2011) examined whether companies quoted on the Nairobi Stock Exchange follow Lintner's model in their dividend policies and planning as is the case in the developed world. In which data from the 48 Nairobi Stock Exchange (NSE) quoted companies for the period 1998 to 2004 was used giving a 336 firmyear data. The data was analyzed to ascertain applicability of the model. The research indicated that on average, NSE companies paid 59.4 percent of their net earnings as dividends and had a dividend yield of 6.1 percent. Also, it emerged that the NSE companies while declaring dividends to be paid in any particular period did not apply the Lintner's dividend model.

Tirongo (2004) led an investigation on dividends arrangement practices for the listed firms at NSE and inferred that there is a positive association between dividend payout and firm performance as well as the value of the firm. He also argued that there was a general regular trend of dividend payment pattern attributed to numbers of factors, such as, dwindling company profits and economic performance that were associated with Financial liberalization.

Kioko (2006) analysed the relationship between dividend changes and future financial performance of companies quoted at the NSE and established that at least in the year of dividend change, there existed a relationship between dividend changes \& future financial performance. The study further found out that the expected relationship between earning period and financial performance earning per share improves firm value. However, for the first and second after dividend change, an insignificant relationship was observed.

\section{Conceptual Framework}

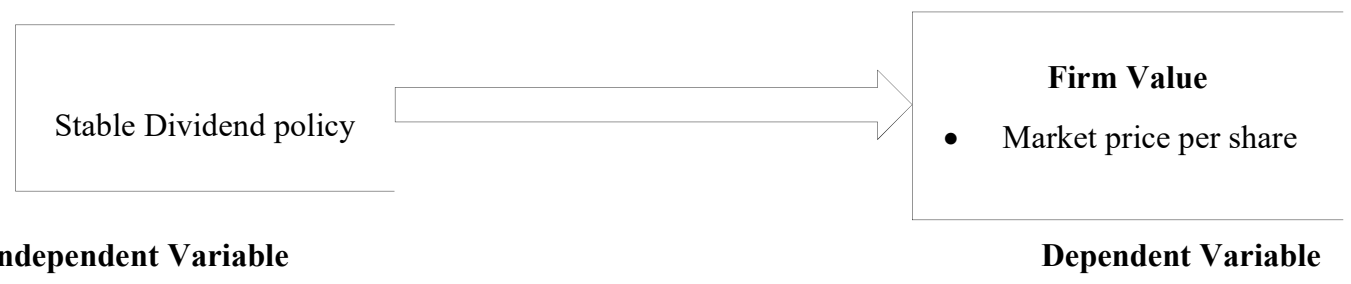

Figure 1. Conceptual Framework

Stable Dividend policy asserts that dividend payment is kept at minimum. Companies using this policy delay paying dividend and do not react to short term changes in earnings. Dividend per share is kept stable and only altered if long term profitability forecast of the firm has been adjusted (Kyle \& Frank, 2013). A low dividend adjustment rate relative to target payout ratio characterizes dividend smoothing. This phenomenon has been witnessed in mature stock markets of USA and Europe. Dividend changes as a result lag behind changes in earnings evident in an economic upturn when retained earnings increase faster than dividends. The converse is true during downturns.

\section{METHODOLOGY}

\section{Research Design}

The study was descriptive design since it used existing data to investigate the effects of stable dividend policy on firms' future market value of the listed firms at the NSE. The data used in this study was obtained from company prospectus and the annual financial statements of companies listed in the Nairobi Securities Exchange for a ten year period that is, from 2006 to 2015. Market price per share will measure firm's value. 
Target Population

The population of the study consisted of 61 firms listed in the Nairobi Securities Exchange.

\section{Sampling and Sample Size}

The sample size comprised of 38 firms listed at NSE. The sample was selected using a purposive technique to ensure only firms with relevant data were involved i.e. Firms which have paid dividends more than once within the period hence a total of 322 firm-year observations were analyzed.

Table 1. Sample Distribution

\begin{tabular}{|c|c|c|}
\hline Category & Number of Firms & Sample Size \\
\hline Agricultural & 7 & 4 \\
\hline Automobiles and Accessories & 4 & 2 \\
\hline Banking & 11 & 7 \\
\hline Commercial and Services & 9 & 6 \\
\hline Construction and Allied & 5 & 3 \\
\hline Energy and Petroleum & 5 & 3 \\
\hline Insurance & 6 & 4 \\
\hline Investment & 3 & 2 \\
\hline Investment services & 1 & 1 \\
\hline Manufacturing and Allied & 9 & 6 \\
\hline Telecommunication and Technology & 1 & 1 \\
\hline Total & 61 & 38 \\
\hline
\end{tabular}

\section{Data Collection Procedure}

This study was based on secondary data, which was collected through documentary analysis of income statements and company prospectus of the sampled listed companies at NSE for a period of ten years from 2006 to 2015 . The annual financial information was obtained from data vendors at the NSE.

Data Analysis and Presentation

The study applied descriptive statistics i.e. mean and trend analysis to analyze data collected and analysis of variance (ANOVA) to test the hypotheses. Dividend policy derived from the firm year observations are determined and related to market value of the respective shares for the period of ten years (from 2006 to 2015). Stable dividend policy is the independent variable while the market value of shares is the dependent variable. Regression analysis was used to establish extend of the relationship and ability to predict stock value given dividend policy. All the tests are done at the 0.05 level of significance.

\section{RESULTS AND DISCUSSIONS}

\section{Descriptive Statistics}

Table 2. Market value Statistics for Dividend policy

\begin{tabular}{lllllll} 
N & Mean & Median & Std. Deviation & Range & Minimum & Maximum \\
\hline 119 & 61.65 & 62.5 & 13.77 & 86.25 & 3.75 & 90
\end{tabular}

From Table 2 stable dividend policy registered market value of Kshs. 61.65 per share and a standard deviation of 13.77 which clearly signifies that it has positive impact on market value of firms listed on NSE. This is consistent with a market whose investors are attracted more by stability of payout than unstable dividends. Out of the 38 companies involved in the study, 17 of them exhibited stable payout and they are classified into four industries namely Automobile, Commercial, Construction and Manufacturing. For these firms, stabilizing dividend payout signals the market that financial prospects for the companies is good and that they promise to sustain payment of the dividends into the future. It is apparent that firms paying stable dividends also paid relatively higher dividends than those that fluctuated their payout. 


\section{Stability of Dividend}

Market segments were studied for their stable dividend payout or otherwise. Figure 2 shows that banking, construction and manufacturing sectors lead in paying stable dividends with each recording 40 observations for stable dividends or low standard deviation for dividend payout. Stable dividend signals brighter prospects for firm because. Stable dividend payer changes in payout pattern is unlikely. Markets have been said to prefer stable dividends to unstable one especially for investors who rely on dividend income to smooth consumption.

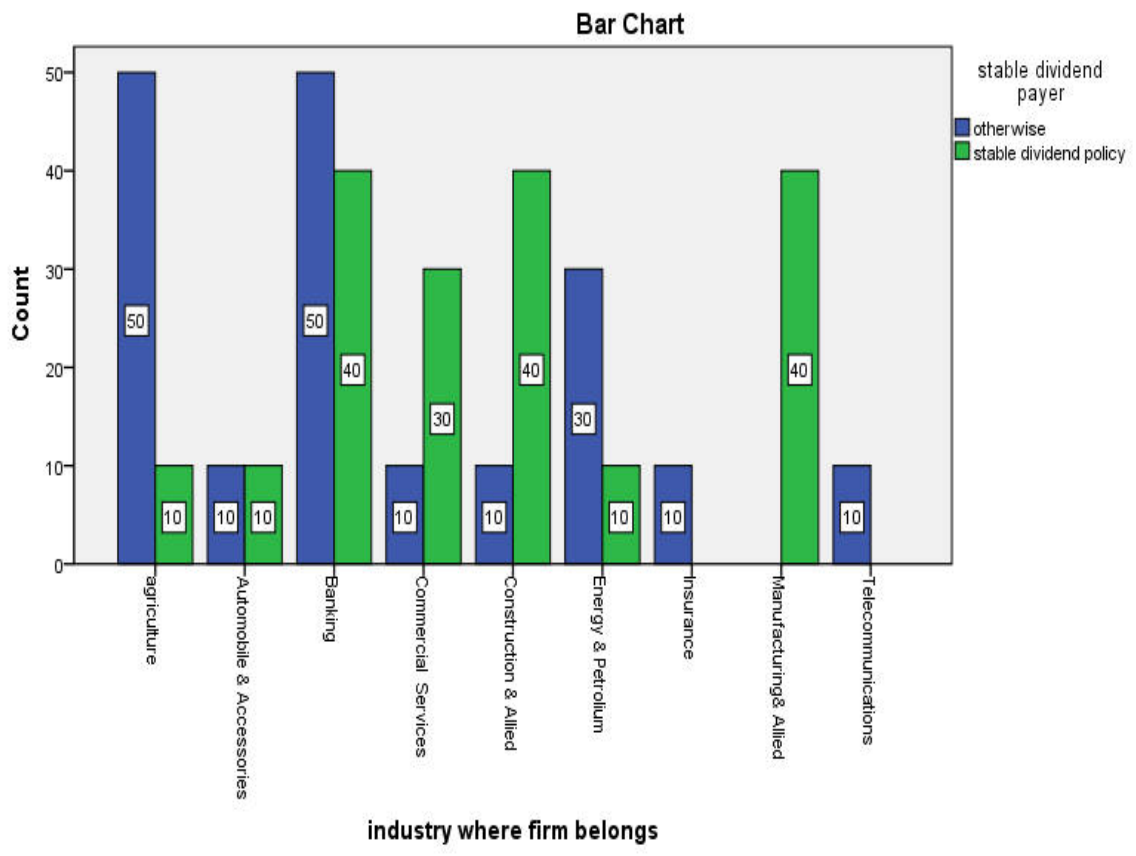

Figure 2. Stable dividend payer observations

\section{Dividend policy of Sampled Firms.}

Out of the 38 companies sampled for their dividend policy, 33 were classified as having a definite policy of paying dividends. A count of the companies said to have had a stable dividend for the period yields 17 companies while 16 paid irregular dividends. A median value for standard deviation of DPS guided the classification. The remaining five companies did not provide sufficient data for classification. High dividend payout between the years 2006 and 2015 was indicated by firm-year observations in the year 2006 and lowest in the year 2012 before declining again to 12 observations in the year 2015 (Figure 3). As more of the low dividend payment data is observed from year 2006 less of the higher dividend payout is noticed for all the firms in the study. 


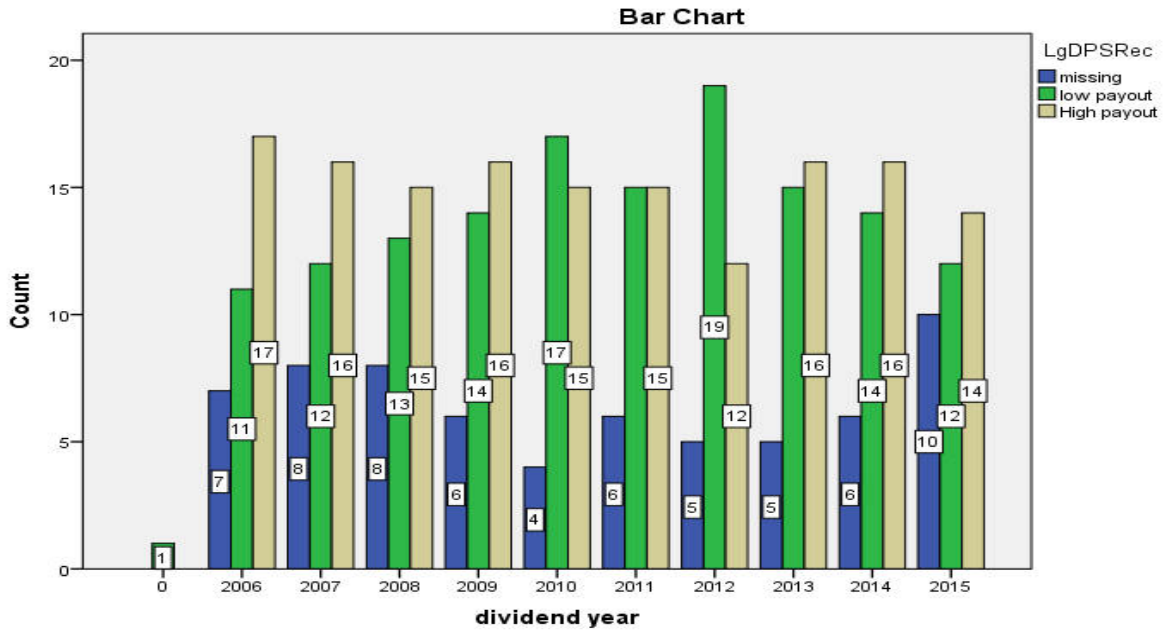

Figure 3. Panel observations for Dividend Payout

The result means that economic conditions deteriorated after the year 2006 to 2012 before improving after 2012 for many listed dividend paying turns. The year 2015 recorded the least number of observed low payouts for the companies sampled in this study. However high dividend paying observations also fluctuated during the period signifying unstable economic environment for the period.

\section{Dividend payout by industry classification}

Figure 4 Indicates banking sector firms posting higher dividend record followed by Agriculture with 81 and 41 observations respectively. The sector with lowest observed firm year data of dividends paid is automobile sector with only 7 observations. On the other hand nonpayment of dividends was led by commercial and services sector with 14 observations while manufacturing reported least number for non-payout of dividends.

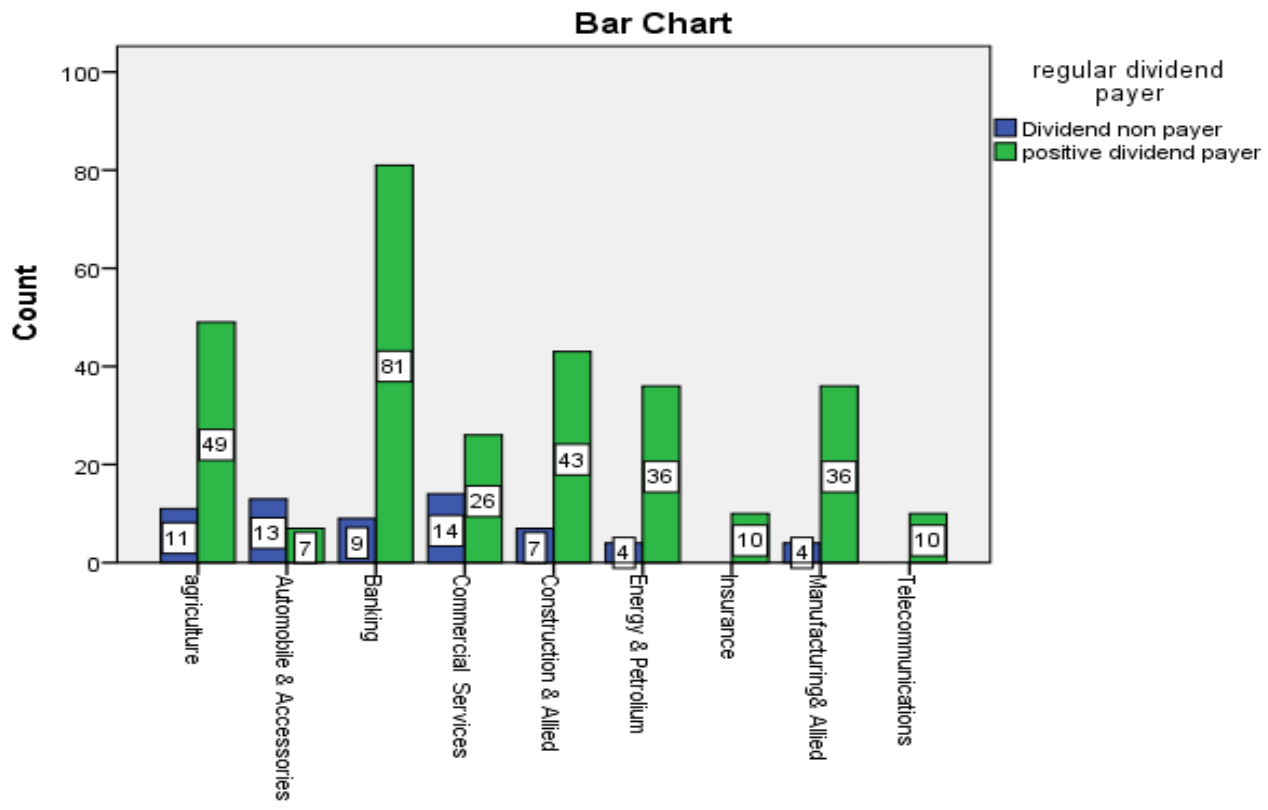

industry where firm belongs

Figure 4. Dividend payout by Sector 
Therefore banking sector is more attractive by their divided paying history while commercial sector and automobile was worst at non payout with 14 and 13 observations respectively.

\section{Inferential Statistics}

Analysis of Variance(ANOVA): Dividend Policy and Firm Value

A One-way between subjects ANOVA was conducted to compare the effect of stable dividend policy on firm's value.

Table 3. ANOVA Table for the Model

\begin{tabular}{|c|c|c|c|c|c|}
\hline & Sum of Squares & Df & $\begin{array}{l}\text { Mean } \\
\text { Square }\end{array}$ & $\mathbf{F}$ & Sig. \\
\hline Between Groups & 1.857 & 2 & .928 & 3.330 & .037 \\
\hline Within Groups & 94.776 & 340 & .279 & & \\
\hline Total & 96.633 & 342 & & & \\
\hline
\end{tabular}

Table 3 shows that there was a statistically significant effect of stable dividend policy on firms value at the $\mathrm{p}<0.05$ level for the policy $[F(2,340)=3.33, p=0.037$. These results suggests that stable dividend policy has an effect on firms value with a significance value of 0.037 hence stable dividend policy pursued by the listed companies' impact market value significantly.

Table 4. Chi-Square Test for Dividend Policy and market Value

\begin{tabular}{lccc}
\hline & Value & df & $\begin{array}{l}\text { Asymptotic Significance (2- } \\
\text { sided) }\end{array}$ \\
\hline Pearson Chi-Square & $12.666^{\mathrm{a}}$ & 2 & .002 \\
Likelihood Ratio & 12.553 & 2 & .002 \\
Linear-by-Linear Association & 8.484 & 1 & .004 \\
N of Valid Cases & 322 & & \\
\hline
\end{tabular}

a. 0 cells $(0.0 \%)$ have expected count less than 5 .

The minimum expected count is 32.34 .

Table 4 shows that stable dividend policy was statistically significantly related to market value as shown by the high chi square value of $12.66 \mathrm{df}$ of 2 and $\mathrm{p}$ value of 0.002 as presented on. Firms in this market favour a more stable dividend policy probably because of its signaling role, agency and information asymmetry concerns.

Regression Analysis

Regression analysis was conducted to establish the relationship between stable dividend policy and firm's value.

MPS $_{\mathrm{it}}=\mathrm{f}\left(\mathrm{X}_{\mathrm{i}}\right)$

MPS $_{\text {it }}=\beta_{1}+\beta_{2} X_{\text {it }}$

$\beta_{1}=$ Intercept coefficient

$\beta_{2}=$ Slope coefficient for dividend policy 
Table 5. Coefficient of Determination

\begin{tabular}{|c|c|c|c|c|c|c|c|c|c|}
\hline \multirow[t]{2}{*}{ Model } & \multirow[t]{2}{*}{$\mathbf{R}$} & \multirow{2}{*}{$\begin{array}{l}\text { R } \\
\text { Squa } \\
\text { re }\end{array}$} & \multirow{2}{*}{$\begin{array}{l}\text { Adjus } \\
\text { ted R } \\
\text { Squar } \\
\text { e }\end{array}$} & \multirow{2}{*}{$\begin{array}{l}\text { Std. } \\
\text { Error } \\
\text { of the } \\
\text { Estimat } \\
\text { e }\end{array}$} & \multicolumn{4}{|c|}{ Change Statistics } & \multirow{2}{*}{$\begin{array}{l}\text { Durbin- } \\
\text { Watson }\end{array}$} \\
\hline & & & & & $\begin{array}{l}\text { R } \\
\text { Square } \\
\text { Change }\end{array}$ & $\begin{array}{l}\mathrm{F} \\
\text { Change }\end{array}$ & $\begin{array}{ll}\mathrm{df} & \mathrm{df} 2 \\
1 & \end{array}$ & $\begin{array}{l}\text { Sig. F } \\
\text { Chang } \\
\text { e }\end{array}$ & \\
\hline 1 & $.807^{\mathrm{a}}$ & .651 & .650 & .31238 & .651 & 546.266 & 293 & .002 & 1.747 \\
\hline
\end{tabular}

\section{a. Predictors: (Constant), DPS by Size}

\section{b. Dependent Variable: MPS}

A regression analysis conducted on panel data of $\mathrm{MPS}_{\mathrm{it}}$ and dividends paid per share by each firm for the period 2006 - 2015 shows that the simple regression model is valid since $F$ value is $546.266, \mathrm{df}_{1}=1 \mathrm{df}_{2}=293, \mathrm{Sig}=0.002$ as shown in Table 5. Stable dividend policy was statistically significant at p level of 0.002 hence the null hypotheses "There is no statistically significant effect of stable dividends policy on firms" market value" is rejected.

Table 6. Regression Statistics Regress LGMPS LgDPS

\begin{tabular}{llll} 
Source & ss & df & ms \\
\hline Model & 51.1317025 & 1 & 51.1317025 \\
Residual & 26.9171372 & 293 & .091867362 \\
\hline Total & 78.0488397 & 294 & .265472244
\end{tabular}

$\begin{array}{ll}\text { Number of obs } & =295 \\ \mathrm{~F}(1,293) & =556.58 \\ \text { Prob }>\text { F } & =0.0000 \\ \text { R-squared } & =0.6551 \\ \text { Adj R-squared } & =0.6539 \\ \text { Root MSE } & =.3031\end{array}$

\begin{tabular}{llllllr}
\hline LGMPS & Coef. & Std. err. & $\mathrm{t}$ & $\mathrm{p}>|\mathrm{t}|$ & [95\% Conf. Interval] \\
\hline LgDPS & .748313 & .031719 & 23.59 & 0.000 & .6858872 & .8107389 \\
cons & 1.580542 & .0194962 & 81.07 & 0.000 & 1.542172 & 1.618913 \\
\hline
\end{tabular}

Statistics for goodness of fit Table 6 yields $\mathrm{R}^{2}=0.655$ which means that a $65.5 \%$ change in firm's market value is due to dividend policy of the listed firms. The remaining percentage $(34.5 \%)$ is explained by other factors not included in the model. The estimated coefficients for intercept and slope representing dividend policy are as presented in equation 2 .

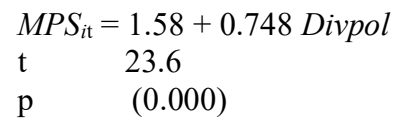

A shift towards stable dividend policy of the listed firms is likely to improve firm's value by shs 0.748 . The change is statistically significant with a t value of 23.6 and an intercept of $1.58(\mathrm{P}=0.000)$ meaning that firms value will be at shs 1.58 with no dividend policy adopted by the listed firms. A strong correlation coefficient was observed between dividends changes and market value of stock at the Nairobi Securities Exchange. It is puzzling however why different firms pursue different policy when market prefers stability. Other firms do not hesitate to omit payout so that dividend data is inconsistent in some periods. This scenario is confusing and should be investigated further.

\section{CONCLUSION}

Stable dividend policy has a positive significant effect on market value of listed firms at NSE with a mean value of 61.65. The policy have a very strong positive association with the market price per share with a correlation coefficient $r$ at 0.81 which means that corporate managers must view dividend payment more favorably because 
as finance manager who are intermediaries between the firm and the capital market, dividend decision made must add value to the stock that is trading at the securities exchange. The right decision must then therefore be one that looks at how to initiate or continue paying dividends with a more stable pattern so that firm value is enhanced. Regression analysis outcome has shown that for firms practicing stable dividend policy, a shilling per share paid as dividend is likely to increase the market value per share by 2.328 shillings hence firms listed at the NSE would be adding value to their firms if they embrace dividend decisions that are directed at stabilizing payout pattern.

\section{RECOMMENDATION}

i. Nairobi Security Exchange as a capital market continues to experience growth and development. Investors in this market are attracted to firms that pay stable dividends and not just pay any pattern of dividends. Cooperate managers therefore should embrace stable dividends payout.

ii. Firm size is irrelevant when it comes to corporate dividend decisions. Therefore this factor should not be considered when making dividend policy decisions in this capital market.

iii. Dividends have a strong association with a stock price and finance manager should ensure dividends are consistently paid to investors so that asymmetric information problems are reduced.

\section{REFERENCES}

Abdul, F. (1993). 'An Empirical Study to Identify Parameters Which are Important in the Determination of Dividends by Publicly Quoted Companies.' Unpublished MBA Project, University of Nairobi

Baker, K., Powell, G. \& Veit, T. (2002). Revisiting the Dividend Puzzle: Do All of the Pieces Now Fit? Review of Financial Economics, 11 (4), pp. 241-261.

Bitok, J. (2004). 'The Effect of Dividend Policy on the Value of the Firms Quoted at the Nairobi Stock Exchange.' Unpublished MBA project, University of Nairobi.

Black, F. (1976). The dividend puzzle. Journal of Portfolio Management, 2, 5-8.

Bulla, D., Namusonge, G. S., Kanali, C. L. (2017). Stability and role of dividend payout among public firms at Nairobi Securities Exchange. $72-77$

Fama, E. F. \& French, K. R. (2001). Disappearing Dividends: Changing Firm Characteristics or Lower Propensity to Pay? Journal of Financial Economics ,60 (1), 3- 43

Frankfurter, G., \& McGoun, E. (2000). Thought Contagion and Financial Economics: The Dividend Puzzle as a Case Study. The Journal of Psychology and Financial Markets, 1(2), 145 - 153.

Gordon M. (1962), The savings, investment and valuation of a corporation. Review of Economics and Statistics, $37-51$.

Ikame, R. (2011). Applicability of Linter's dividend policy to companies quoted on the Nairobi stock exchange. Kenyatta university.

Karanja, J. (1987). Dividend Practices of Publicly Quoted Companies in Kenya. Unpublished MBA Project, University of Nairobi

Kyle, A.P. \& Frank W.B. (2013). Dividend policy and stock price volatility in the US Equity capital market. ASBBS Annual Conference 20(1).219-231.

Kioko, M. (2006). An Analysis of the Relationship between Dividend Changes \& Future Profitability of Companies Quoted at the Nairobi Stock Exchange. Unpublished MBA project, University of Nairobi.

Lintner, J. (1956). Distribution of Income of Corporations among Dividend, Retained earnings and taxes. American Economic Review.

Modigliani, F. \& Miller, M.H. (1961). Dividend Policy, Growth, and the Valuation of Shares. The Journal of Business, 34(4), 411-433. 
Mizuno, M. (2007). Payout policy of Japanese firms: Analysis on the survey of four industries listed on the Tokyo Stock Exchange. Pacific Economic Review, 12(5), 631 - 650.

Morrison, L., Breen, J. \& Shameen, A. (2003). Small business growth. Intention, ability and opportunity. J. Small Bus. Manage, 41(4), 417-425.

Njoroge, B. (2001). The relationship between dividend policies and return on assets and return on equity of companies listed at the NSE. Unpublished MBA project. University of Nairobi.

Omollo, J. \& Kimathi, H. (2011). The applicability of the constant dividend model for companies listed at the Nairobi stock exchange. University of Nairobi.

Tiriongo, T. (2004). Dividend Policy Practices of the Companies Listed at the Nairobi Stock Exchange. Unpublished MBA Project, University of Nairobi.

Walter, J. (1967). Dividend policy and enterprise valuation. Belmont, Calif-Wadsworth Publishers co.

Wandeto, P. (2005). An Empirical Investigation of the Relationship between Dividend Changes and Earnings. Unpublished MBA project, Nairobi University. 